\title{
Vanishing coccolith vital effects with alleviated carbon limitation
}

\author{
M. Hermoso, I. Z. X. Chan, H. L. O. McClelland, A. M. C. Heureux, and R. E. M. Rickaby \\ University of Oxford, Department of Earth Sciences, South Parks Road, Oxford OX1 3AN, UK \\ Correspondence to: M. Hermoso (michael.hermoso@earth.ox.ac.uk)
}

Received: 14 August 2015 - Published in Biogeosciences Discuss.: 24 September 2015

Revised: 15 December 2015 - Accepted: 16 December 2015 - Published: 15 January 2016

\begin{abstract}
By recreating a range of geologically relevant concentrations of dissolved inorganic carbon (DIC) in the laboratory, we demonstrate that the magnitude of the vital effects in both carbon and oxygen isotopes of coccolith calcite of multiple species relates to ambient DIC concentration. Under high DIC levels, all the examined coccoliths exhibit significantly reduced isotopic offsets from inorganic calcite compared to the substantial vital effects expressed at low (preindustrial and present-day) DIC concentrations. The supply of carbon to the cell exerts a primary control on biological fractionation in coccolith calcite via the modulation of coccolithophore growth rate, cell size and carbon utilisation by photosynthesis and calcification, altogether accounting for the observed interspecific differences between coccolith species. These laboratory observations support the recent hypothesis from field observations that the appearance of interspecific vital effect in coccolithophores coincides with the long-term Neogene decline of atmospheric $\mathrm{CO}_{2}$ concentrations and bring further valuable constraints by demonstrating a convergence of all examined species towards inorganic values at high $p \mathrm{CO}_{2}$ regimes. This study provides palaeoceanographers with a biogeochemical framework that can be utilised to further develop the use of calcareous nannofossils in palaeoceanography to derive sea surface temperature and $p \mathrm{CO}_{2}$ levels, especially during periods of relatively elevated $p \mathrm{CO}_{2}$ concentrations, as they prevailed during most of the Meso-Cenozoic.
\end{abstract}

\section{Introduction}

The quest to generate reliable and accurate palaeoenvironmental reconstructions is hindered by uncertainties in our current proxies from the sedimentary archive. One prominent caveat comes from the biological origin of sedimen- tary calcareous particles in marine and oceanic realms. As a consequence of the biological controls on chemical signals in algae, most biominerals do not precipitate in equilibrium conditions and the compositional departure between biocarbonates and an inorganic reference is commonly referred to as the vital effect. Therefore, geochemical data from ancient biomineralising organisms must be corrected in order to derive the primary signals from palaeoseawater. In the case of the foraminifera, corals and coccoliths, the foremost carbonate producers in the marine realm, there has been a considerable number of studies during which living organisms were cultured in strictly controlled environmental conditions and their biominerals measured for a range of isotopic systems to generate empirical proxy calibrations (Erez and Luz, 1982; Dudley et al., 1986; Spero et al., 1997; Bemis et al., 1998; Ziveri et al., 2003; Tripati et al., 2010; Rickaby et al., 2010; Rollion-Bard et al., 2011; Grauel et al., 2013; Hermoso et al., 2014; Minoletti et al., 2014; Hermoso, 2015).

Another important aim in palaeoceanography is to determine whether the physiology-induced fractionation for a given taxon was constant through time from an evolutionary perspective, and over shorter time intervals comprising large climatic fluctuations, in turn inducing an environmentally driven modulation of the vital effect (Hermoso, 2014). In the absence of more reliable information, the Uniformitarianism principle - by which, the processes that were operating in the geological past still exist today, and vice versa is commonly applied for elucidating vital effects and reconstructing primary oceanographic signals.

Although coccoliths are relatively challenging to extract at the species-specific level from sediments compared to foraminifera, coccolith-based studies represent a growing field since the pioneering work by Anderson and Steinmetz (1981). To better interpret coccolith isotope signals and generate more reliable palaeoenvironmental estimates from 
these cosmopolitan organisms, we need to gain a broader picture of their vital effects, and more specifically determine how environmental parameters govern their magnitude. Several studies have specifically measured coccolith $\delta^{18} \mathrm{O}$ with changing temperature in laboratory cultures in order to determine and calibrate the temperature $-\delta^{18} \mathrm{O}$ relationship for a wide range of species (Dudley et al., 1986; Ziveri et al., 2003; Candelier et al., 2013; Stevenson et al., 2014). Meanwhile, other culture studies have kept temperature constant but have manipulated the carbonate chemistry of the culture medium and the irradiance level (Ziveri et al., 2003; Rickaby et al., 2010; Hermoso, 2015) and found substantial modulation of the oxygen isotope vital effect with these parameters at constant temperature. In most cases, only one parameter was controlled at a time, and we are lacking cross-parameter investigations that are required for the effective application of palaeoproxies. In nature, environmental parameters generally co-vary, such as sea surface temperatures and $p \mathrm{CO}_{2}$ concentrations. This is illustrated by the recent natural environment study by Hermoso et al. (2015) analysing coccoliths microseparated from core top sediments, which further illustrates the intricate (multi-parameter) control of coccolith oxygen and carbon isotope compositions $\left(\delta^{18} \mathrm{O}\right.$ and $\delta^{13} \mathrm{C}$, respectively).

These biogeochemical proxies raise questions regarding what vital effect coefficients should be applied to ancient coccolith species extracted from Meso-Cenozoic sediments as temperature and $p \mathrm{CO}_{2}$ significantly evolved before reaching preindustrial levels. In the present study, we document a multi-species control of stable carbon and oxygen isotope composition under a wide range of DIC (hence $p \mathrm{CO}_{2}$ ) levels at a constant $\mathrm{pH}$ of 8.2 (total scale) recreated in the laboratory. As varying the availability of ambient DIC substrate may modulate the degree of carbon limitation for algal growth (cell division rate and size), this culture approach will allow us to determine whether the vital effect is constant for a given coccolith species or changes with the environment, and in particular in response to ambient carbon concentrations.

\section{Material and methods}

\subsection{Coccolithophore strains studied}

Emiliania huxleyi has attracted most recent attention in coccolithophore research due to its dominance in present-day oceans, its importance in biogeochemical cycles, and accompanying relevance to ocean chemistry and climate of the Anthropocene (e.g. Bidigare et al., 1997; Riebesell et al., 2000; Iglesias-Rodriguez et al., 2008; De Bodt et al., 2010; Suffrian et al., 2011; Müller et al., 2012; Bach et al., 2013; Sett et al., 2014; Tchernov et al., 2014; Young et al., 2014; Aloisi, 2015; Holtz et al., 2015). The strain RCC 1256 used in this study produces lightly calcified coccoliths assigned to the morphotype A (Langer and Bode, 2011). From a geological point of view however, palaeoceanographic applications to $E$. huxleyi only cover a narrow time interval, as this species has only recently evolved ( $\sim 268 \mathrm{kyr}$ ago; Thierstein et al., 1977).

The species Calcidiscus leptoporus has a longer geological record, with its first appearance in pelagic sediments reported in the Miocene (Bown, 1998). This species was studied in culture to assess changes in the morphology of its coccoliths with altered medium chemistry (Langer and Bode, 2011) and isotopically (Ziveri et al., 2012; Candelier et al., 2013; Hermoso et al. 2014). In the present study, we used the strain RCC 1129 corresponding to the intermediate morphotype on the merit of coccolith size. The same monoclonal strain was previously cultured by Candelier et al. (2013) and Hermoso et al. (2014) where cells were successively subjected to change in temperature and medium oxygen composition.

The large and relatively ancient taxon Coccolithus pelagicus (strain RCC 1202 being studied here) corresponds to the subspecies braarudii. This taxon has been examined isotopically in culture (Rickaby et al., 2010; Hermoso et al. 2014; Stevenson et al., 2014). Amongst all extant coccolithophore species, $C$. pelagicus has the longest geological record, with a first occurrence of the informally defined " $C$. pelagicus group" dated back to the Palaeogene ( $\sim 66 \mathrm{Myr}$ ago).

Pleurochrysis placolithoides has no direct geological relevance. The occurrence of this species has not been reported in the fossil record owing to its nearshore ecology compared to most coccolithophore species living in more open ocean settings (Young et al., 2003). However, its coccosphere size is in between $C$. pelagicus and C. leptoporus - all taxa belonging to the Coccolithales order. As these two strains have contrasting vital effects, it is interesting to study an intermediate cell size to further explore a link between cell morphology and coccolith isotopic composition. The strain used in this study is RCC 1401 .

\subsection{Culture medium preparation}

A raw batch of natural seawater collected from the English Channel (station L4; $50^{\circ} 15.00^{\prime} \mathrm{N}-4^{\circ} 13.02^{\prime} \mathrm{W}$ ) was supplied by MBA, Plymouth (UK). The batch of seawater (salinity $\sim 33$ ) was first acidified using concentrated $\mathrm{HCl}$ to reach $\mathrm{pH}$ $\sim 2$, conditions under which most of the dissolved inorganic carbon was present in the form of aqueous $\mathrm{CO}_{2}$. The batch was bubbled overnight with pure $\mathrm{N}_{2}$ to remove DIC. Subsequently, $\mathrm{pH}$ was brought back to a value around 8 by addition of $\mathrm{NaOH}$. Still under $\mathrm{N}_{2}$ purge, we amended the medium in nitrate, phosphate, EDTA and vitamins according to the $K / 2$ recipe (see Hermoso et al., 2014, for further details). To obtain the desired DIC level $\left(2,4,6,8,10\right.$ and $\left.12 \mathrm{mmol} \mathrm{kg}_{\mathrm{sw}}^{-1}\right)$, we proceeded to add calculated amounts of $\mathrm{NaHCO}_{3}$ powder (Sigma - batch CAS 144-55-8) in different aliquots with immediate $\mathrm{pH}$ adjustment to 8.2 (total scale), after which each DIC batch then was promptly filtered-sterilised and kept in Teflon-sealed flasks without headspace. Prior to inoculation, each medium was measured for its total alkalinity using a 
Table 1. Numerical data set.

\begin{tabular}{|c|c|c|c|c|c|c|c|c|c|c|c|c|c|c|c|c|c|c|c|}
\hline & $\begin{array}{c}\text { Target } \\
\text { DIC } \\
\mathrm{mmol} \mathrm{kg}^{-1}\end{array}$ & $\begin{array}{c}\text { Temperature } \\
{ }^{\circ} \mathrm{C}\end{array}$ & Salinity & $\begin{array}{c}\mathrm{pH} \\
\text { total } \\
\text { scale }\end{array}$ & $\begin{array}{r}\text { TA } \\
\mu \mathrm{mol} \mathrm{kg}{ }^{-1}\end{array}$ & $\begin{array}{r}\mathrm{CO}_{2 \text { aq }} \\
\mu \mathrm{mol} \mathrm{kg} \mathrm{kg}^{-1}\end{array}$ & $\begin{array}{r}\mathrm{HCO}_{3}^{-} \\
\mu \mathrm{mol} \mathrm{kg}{ }^{-1}\end{array}$ & $\begin{array}{r}\mathrm{CO}_{3}^{2-} \\
\mu \mathrm{mol} \mathrm{kg-1}\end{array}$ & $\begin{array}{r}p \mathrm{CO}_{2} \\
\mu \mathrm{atm}\end{array}$ & $\begin{array}{r}\delta^{18} \mathrm{O}_{\mathrm{sw}} \\
\% \mathrm{~V} \text { V-SMOW }\end{array}$ & $\begin{array}{r}\delta^{13} \mathrm{C}_{\text {DIC }} \\
\% \circ \mathrm{V}-\mathrm{PDB}\end{array}$ & $\begin{array}{l}\delta^{13} \mathrm{C}_{\text {inorg }} \\
\% \text { V V-PDB }\end{array}$ & $\begin{array}{l}\delta^{18} \mathrm{O}_{\text {innorg }} \\
\% \% \text { V-PDB }\end{array}$ & $\begin{array}{r}\delta^{13} \mathrm{C}_{\mathrm{c}} \\
\% o \text { V-PDB }\end{array}$ & $\begin{array}{r}\delta^{18} \mathrm{O}_{c} \\
\% o \mathrm{~V}-\mathrm{PDB}\end{array}$ & $\begin{array}{r}\delta-{ }^{18} \mathrm{O}_{\mathrm{c}-\text { sw }} \\
\% \mathrm{~V} \text { V-PDB- } \\
\text { V-SMOW }\end{array}$ & $\begin{array}{r}\delta-{ }^{13} \mathrm{C}_{\mathrm{c}-\mathrm{DIC}} \\
\% \% \text { V-PDB }\end{array}$ & $\begin{array}{r}\mu \\
\mathrm{day}^{-1}\end{array}$ & $\begin{array}{r}\text { Coccosphere } \\
\text { diameter } \\
\mu \mathrm{m}\end{array}$ \\
\hline Emiliania & 2 & 15 & 33 & 8.2 & 2370 & 10.1 & 1780.8 & 209.1 & 267 & 0.50 & -2.54 & -1.54 & -0.04 & -0.73 & 2.77 & 2.27 & 1.81 & 0.69 & 4.94 \\
\hline \multirow{11}{*}{$\begin{array}{l}\text { huxleyi } \\
\text { huma }\end{array}$} & 2 & 15 & 33 & 8.2 & 2370 & 10.1 & 1780.8 & 209.1 & 267 & 0.50 & -2.54 & -1.54 & -0.04 & -1.00 & 2.51 & 2.01 & 1.54 & 0.68 & 5.01 \\
\hline & 4 & 15 & 33 & 8.2 & 4406 & 20.2 & 3561.6 & 418.2 & 535 & 0.50 & -2.54 & -1.54 & -0.04 & -1.05 & 1.96 & 1.46 & 1.49 & 0.73 & 5.27 \\
\hline & 4 & 15 & 33 & 8.2 & 4406 & 19.9 & 3561.6 & 418.2 & 535 & 0.50 & -2.54 & -1.54 & -0.04 & -1.10 & 2.56 & 2.06 & 1.44 & 0.69 & 5.30 \\
\hline & 6 & 15 & 33 & 8.2 & 6590 & 30.3 & 5342.4 & 627.4 & 802 & 0.50 & -2.54 & -1.54 & -0.04 & -1.31 & 2.36 & 1.86 & 1.23 & 0.77 & 5.41 \\
\hline & 6 & 15 & 33 & 8.2 & 6590 & 29.8 & 5342.4 & 627.4 & 802 & 0.50 & -2.54 & -1.54 & -0.04 & -1.28 & 2.35 & 1.85 & 1.26 & 0.78 & 5.33 \\
\hline & 8 & 15 & 33 & 8.2 & 8535 & 40.4 & 7123.2 & 836.5 & 1070 & 0.50 & -2.54 & -1.54 & -0.04 & -1.49 & 1.87 & 1.37 & 1.05 & 0.78 & 5.37 \\
\hline & 8 & 15 & 33 & 8.2 & 8535 & 40.4 & 7123.2 & 836.5 & 1070 & 0.50 & -2.54 & -1.54 & -0.04 & -1.43 & 1.96 & 1.46 & 1.11 & 0.79 & 5.47 \\
\hline & 10 & 15 & 33 & 8.2 & 10853 & 50.5 & 8903.9 & 1045.6 & 1337 & 0.50 & -2.54 & -1.54 & -0.04 & -1.56 & 1.94 & 1.44 & 0.98 & 0.73 & 5.50 \\
\hline & 10 & 15 & 33 & 8.2 & 10853 & 50.5 & 8903.9 & 1045.6 & 1337 & 0.50 & -2.54 & -1.54 & -0.04 & -1.61 & 1.82 & 1.32 & 0.93 & 0.73 & 5.49 \\
\hline & 12 & 15 & 33 & 8.2 & 12963 & 60.6 & 10684.7 & 1254.7 & 1604 & 0.50 & -2.54 & -1.54 & -0.04 & -1.85 & 1.81 & 1.31 & 0.69 & 0.76 & 5.53 \\
\hline & 12 & 15 & 33 & 8.2 & 12963 & 59.6 & 10684.7 & 1254.7 & 1604 & 0.50 & -2.54 & -1.54 & -0.04 & -1.81 & 1.75 & 1.25 & 0.73 & 0.72 & 5.48 \\
\hline Pleurochrysis & 2 & 15 & 33 & 8.2 & 2370 & 10.1 & 1780.8 & 209.1 & 267 & 0.50 & -2.54 & -1.54 & -0.04 & NA & NA & & & 0.56 & 16.12 \\
\hline \multirow{11}{*}{ placolithoides } & 2 & 15 & 33 & 8.2 & 2370 & 10.1 & 1780.8 & 209.1 & 267 & 0.50 & -2.54 & -1.54 & -0.04 & NA & NA & & & NA & NA \\
\hline & 4 & 15 & 33 & 8.2 & 4406 & 20.2 & 3561.6 & 418.2 & 535 & 0.50 & -2.54 & -1.54 & -0.04 & NA & $\mathrm{NA}$ & & & $\mathrm{NA}$ & NA \\
\hline & 4 & 15 & 33 & 8.2 & 4406 & 19.9 & 3561.6 & 418.2 & 535 & 0.50 & -2.54 & -1.54 & -0.04 & -0.92 & -1.68 & -2.18 & 1.62 & 0.54 & 16.55 \\
\hline & 6 & 15 & 33 & 8.2 & 6590 & 30.3 & 5342.4 & 627.4 & 802 & 0.50 & -2.54 & -1.54 & -0.04 & -1.11 & -0.26 & -0.76 & 1.43 & 0.55 & 16.31 \\
\hline & 6 & 15 & 33 & 8.2 & 6590 & 29.8 & 5342.4 & 627.4 & 802 & 0.50 & -2.54 & -1.54 & -0.04 & -1.09 & -0.19 & -0.69 & 1.45 & 0.58 & 16.26 \\
\hline & 8 & 15 & 33 & 8.2 & 8535 & 40.4 & 7123.2 & 836.5 & 1070 & 0.50 & -2.54 & -1.54 & -0.04 & -0.94 & -0.32 & -0.82 & 1.60 & 0.53 & 16.33 \\
\hline & 8 & 15 & 33 & 8.2 & 8535 & 40.4 & 7123.2 & 836.5 & 1070 & 0.50 & -2.54 & -1.54 & -0.04 & -1.32 & -0.51 & -1.01 & 1.22 & 0.51 & 16.43 \\
\hline & 10 & 15 & 33 & 8.2 & 10853 & 50.5 & 8903.9 & 1045.6 & 1337 & 0.50 & -2.54 & -1.54 & -0.04 & -1.54 & -0.05 & -0.55 & 1.00 & 0.58 & 16.56 \\
\hline & 10 & 15 & 33 & 8.2 & 10853 & 50.5 & 8903.9 & 1045.6 & 1337 & 0.50 & -2.54 & -1.54 & -0.04 & -1.54 & -0.05 & -0.55 & 1.00 & 0.56 & 16.56 \\
\hline & 12 & 15 & 33 & 8.2 & 12963 & 60.6 & 10684.7 & 1254.7 & 1604 & 0.50 & -2.54 & -1.54 & -0.04 & -1.40 & 0.21 & -0.29 & 1.14 & 0.56 & 16.53 \\
\hline & 12 & 15 & 33 & 8.2 & 12963 & 59.6 & 10684.7 & 1254.7 & 1604 & 0.50 & -2.54 & -1.54 & -0.04 & -1.55 & 0.14 & -0.36 & 0.99 & 0.56 & 16.59 \\
\hline Calcidiscus & 2 & 15 & 33 & 8.2 & 2370 & 10.1 & 1780.8 & 209.1 & 267 & 0.50 & -2.54 & -1.54 & -0.04 & NA & NA & & & 0.31 & 9.83 \\
\hline \multirow[t]{11}{*}{ leptoporus } & 2 & 15 & 33 & 8.2 & 2370 & 10.1 & 1780.8 & 209.1 & 267 & 0.50 & -2.54 & -1.54 & -0.04 & -3.72 & -0.91 & -1.41 & -1.18 & 0.29 & 9.53 \\
\hline & 4 & 15 & 33 & 8.2 & 4406 & 20.2 & 3561.6 & 418.2 & 535 & 0.50 & -2.54 & -1.54 & -0.04 & -3.34 & -0.96 & -1.46 & -0.80 & 0.31 & 9.61 \\
\hline & 4 & 15 & 33 & 8.2 & 4406 & 19.9 & 3561.6 & 418.2 & 535 & 0.50 & -2.54 & -1.54 & -0.04 & -3.32 & -0.51 & -1.01 & -0.78 & 0.31 & 9.54 \\
\hline & 6 & 15 & 33 & 8.2 & 6590 & 30.3 & 5342.4 & 627.4 & 802 & 0.50 & -2.54 & -1.54 & -0.04 & -2.74 & -0.13 & -0.63 & -0.20 & 0.30 & 9.34 \\
\hline & 6 & 15 & 33 & 8.2 & 6590 & 29.8 & 5342.4 & 627.4 & 802 & 0.50 & -2.54 & -1.54 & -0.04 & -2.72 & -0.24 & -0.74 & -0.18 & 0.30 & 9.80 \\
\hline & 8 & 15 & 33 & 8.2 & 8535 & 40.4 & 7123.2 & 836.5 & 1070 & 0.50 & -2.54 & -1.54 & -0.04 & NA & NA & & & 0.20 & 10.10 \\
\hline & 8 & 15 & 33 & 8.2 & 8535 & 40.4 & 7123.2 & 836.5 & 1070 & 0.50 & -2.54 & -1.54 & -0.04 & -2.86 & -0.44 & -0.94 & -0.32 & 0.21 & \\
\hline & 10 & 15 & 33 & 8.2 & 10853 & 50.5 & 8903.9 & 1045.6 & 1337 & 0.50 & -2.54 & -1.54 & -0.04 & -2.64 & 0.02 & -0.48 & -0.10 & 0.21 & 9.53 \\
\hline & 10 & 15 & 33 & 8.2 & 10853 & 50.5 & 8903.9 & 1045.6 & 1337 & 0.50 & -2.54 & -1.54 & -0.04 & -2.75 & -0.09 & -0.59 & -0.21 & 0.21 & 9.48 \\
\hline & 12 & 15 & 33 & 8.2 & 12963 & 60.6 & 10684.7 & 1254.7 & 1604 & 0.50 & -2.54 & -1.54 & -0.04 & -1.70 & -0.11 & -0.61 & 0.84 & 0.18 & 9.30 \\
\hline & 12 & 15 & 33 & 8.2 & 12963 & 59.6 & 10684.7 & 1254.7 & 1604 & 0.50 & -2.54 & -1.54 & -0.04 & -2.15 & 0.20 & -0.30 & 0.39 & 0.19 & 9.24 \\
\hline & 2 & 15 & 33 & 8.2 & 2370 & 10.1 & 1780.8 & 209.1 & 267 & 0.50 & -2.54 & -1.54 & -0.04 & -4.13 & 1.04 & 0.54 & -1.59 & 0.53 & 18.65 \\
\hline \multirow[t]{11}{*}{ pelagicus } & 2 & 15 & 33 & 8.2 & 2370 & 10.1 & 1780.8 & 209.1 & 267 & 0.50 & -2.54 & -1.54 & -0.04 & -4.04 & 0.95 & 0.45 & -1.50 & 0.51 & 18.65 \\
\hline & 4 & 15 & 33 & 8.2 & 4406 & 20.2 & 3561.6 & 418.2 & 535 & 0.50 & -2.54 & -1.54 & -0.04 & -2.24 & 1.26 & 0.76 & 0.30 & 0.45 & 18.03 \\
\hline & 4 & 15 & 33 & 8.2 & 4406 & 19.9 & 3561.6 & 418.2 & 535 & 0.50 & -2.54 & -1.54 & -0.04 & -2.25 & 1.17 & 0.67 & 0.29 & 0.42 & 18.03 \\
\hline & 6 & 15 & 33 & 8.2 & 6590 & 30.3 & 5342.4 & 627.4 & 802 & 0.50 & -2.54 & -1.54 & -0.04 & -2.03 & NA & & 0.51 & 0.33 & 18.14 \\
\hline & 6 & 15 & 33 & 8.2 & 6590 & 29.8 & 5342.4 & 627.4 & 80 & 0.50 & -2.54 & -1.54 & -0 & -2.15 & $\mathrm{NA}$ & & 0.39 & 0.32 & 18.14 \\
\hline & 8 & 15 & 33 & 8.2 & 85 & 40 & 712 & 836 & 107 & 0. & -2 & -1.54 & -0 & -1.55 & 1.02 & 0.52 & 0.99 & 0.27 & 17.80 \\
\hline & 8 & 15 & 33 & 8.2 & 85 & 40 & 7123.2 & 836 & 10 & 0.5 & -2 & -1.54 & -0.04 & -1.77 & 0.74 & 0.24 & 0.77 & 0.24 & 17.80 \\
\hline & 10 & 15 & 33 & 8.2 & 10853 & 50.5 & 8903.9 & 1045.6 & 1337 & 0.50 & -2.54 & -1.54 & -0.04 & -1.33 & 0.84 & 0.34 & 1.21 & 0.27 & 16.76 \\
\hline & 10 & 15 & 33 & 8.2 & 10853 & 50.5 & 8903.9 & 1045.6 & 1337 & 0.50 & -2.54 & -1.54 & -0.04 & NA & $\mathrm{NA}$ & & & 0.23 & 16.76 \\
\hline & 12 & 15 & 33 & 8.2 & 12963 & 60.6 & $\begin{array}{r}10684.7 \\
\end{array}$ & 1254.7 & 1604 & 0.50 & -2.54 & -1.54 & -0.04 & -1.45 & 0.96 & 0.46 & 1.09 & 0.11 & 16.58 \\
\hline & 12 & 15 & 33 & 8.2 & 12963 & 59.6 & 10684.7 & 1254.7 & 1604 & 0.50 & -2.54 & -1.54 & -0.04 & -1.48 & 0.86 & 0.36 & 1.06 & 0.12 & 16.58 \\
\hline
\end{tabular}

916 Ti Touch automatic titrator (Metrohm) (Table 1). Successive alterations of the carbonate chemistry, due to the addition of $\mathrm{HCl}, \mathrm{NaHCO}_{3}$ and $\mathrm{NaOH}$, did not induce change in total alkalinity compared to the original seawater batch, and there was a very good agreement between target and measured DIC concentrations for each batch (within a range of $5 \%)$.

\subsection{Cell density, size and growth}

During the acclimation and culture phases, cells were maintained at $15^{\circ} \mathrm{C}$ and illuminated under a daily $14 \mathrm{~h} / 10 \mathrm{~h}$ light/dark cycle in Sanyo MLR-351 plant growth chambers. The irradiance was measured as $150 \mu$ mol photons $\mathrm{m}^{-2} \mathrm{~s}^{-1}$. Duplicate culture batches were performed semi-continuously to allow DIC to remain stable with cell growth and preferential $\mathrm{CO}_{2}$ assimilation and utilisation by the cells leading to increasing $\mathrm{pH}$ (Hermoso, 2014), which conforms to experimental guidelines (Barry et al., 2010). Unfortunately, due to this experimental set-up, too low an amount (mass) of harvested culture residues has prevented us from generating meaningful PIC / POC ratios for this study.

The evolution of culture growth was determined by cell enumeration made every 2 days, approximately $3 \mathrm{~h}$ after the onset of the illuminated phase using a Beckman Coulter
Counter Series Z2 apparatus fitted with a $100 \mu \mathrm{m}$ aperture tube. The diluent used was ISOTON II obtained from Beckman Ltd. Calibration of spherical-equivalent coccosphere sizes was performed daily using $10.16 \mu \mathrm{m}$ diameter latex beads provided by the same company. Coccosphere sizes were determined by the mode of Gaussian distribution on the coccospheres given by the Coulter Counter device (Table 1). The specific growth rates $(\mu)$ were calculated from cell densities measured at time of culture harvest $\left(c_{f}\right)$ and 2 days prior to that $\left(c_{f-2}\right)$, using the formula

$\mu\left[\right.$ day $\left.^{-1}\right]=\left[\ln \left(c_{f}\right)-\ln \left(c_{f-2}\right)\right] / 2$,

where cell concentrations are in number of cells per $\mathrm{mL}$ of culture medium.

\subsection{Isotopic analyses}

Carbon and oxygen isotope compositions of coccolith calcite and the oxygen isotopic ratios from water media were measured as described in Hermoso et al. (2014). In brief, coccolith calcites from rinsed and oxidised culture residues were measured using a VG Isogas Prism II mass spectrometer with an on-line VG Isocarb at Oxford University. Results $\left(\delta^{18} \mathrm{O}_{\mathrm{c}}\right.$ and $\left.\delta^{13} \mathrm{C}_{\mathrm{c}}\right)$ are expressed against the international V-PDB reference (Table 1). Medium $\delta^{18} \mathrm{O}$ composi- 
tions $\left(\delta^{18} \mathrm{O}_{\text {sw }}\right)$ were determined by gas-water exchange on a Delta Gas Bench II coupled to a Delta V Advantage mass spectrometer at the University of Oxford. A similar value was obtained for all the DIC batches, with a typical value of $+0.50 \%$ V-SMOW.

The ${ }^{13} \mathrm{C}$ of $\mathrm{NaHCO}_{3}$ powder used was directly measured on the Prism with a value of $-2.54 \%$ V-PDB. Subsequently, $\delta^{13} \mathrm{C}$ of DIC $\left(\delta^{13} \mathrm{C}_{\text {DIC }}\right)$ were measured at Cambridge University using a Thermo Gas Bench attached to a Delta V mass spectrometer, and isotopic values were similar for each batch (within typical error of $\pm 0.1 \%$ ) and indistinguishable from that of the $\mathrm{NaHCO}_{3}$ powder employed to amend the growth milieus.

The magnitude of the vital effects for the oxygen and carbon isotope systems is expressed as the isotopic offset of coccolith calcite from inorganic calcite $\left(\delta^{18} \mathrm{O}_{\text {inorg }}\right.$ and $\delta^{13} \mathrm{C}_{\text {inorg }}$, respectively) calculated using the equations provided by Kim and O’Neil (1997) and Romanek et al. (1992).

$$
\begin{aligned}
\left.{ }^{18} \mathrm{O} \text { Vital effect [\%。V-PDB }\right] & =\delta^{18} \mathrm{O}_{\mathrm{c}}[\% \circ \mathrm{V}-\mathrm{PDB}] \\
& -\delta^{18} \mathrm{O}_{\text {inorg }}[\% \circ \mathrm{V}-\mathrm{PDB}],
\end{aligned}
$$

where $\delta^{18} \mathrm{O}_{\text {inorg }}$ is calculated after the equation of Kim and O'Neil (1997) and Bemis et al. (1998). We note that this computed oxygen isotopic composition is indistinguishable from that of Watkins et al. (2014) with a biogenic-relevant kinetic effect (see Hermoso, 2015). For our experiments, a constant $\delta^{18} \mathrm{O}_{\text {inorg }}$ value of $-0.04 \%$ V-PDB was calculated for a temperature of $15^{\circ} \mathrm{C}$ and an oxygen isotope composition of the culture medium of $+0.5 \%$ V-SMOW.

$$
\begin{aligned}
\left.{ }^{13} \mathrm{C} \text { Vital effect [\%०V-PDB }\right] & =\delta^{13} \mathrm{C}_{\mathrm{c}}[\% \circ \mathrm{V}-\mathrm{PDB}] \\
& -\delta^{13} \mathrm{C}_{\mathrm{inorg}}[\% \text { V-PDB }],
\end{aligned}
$$

where $\delta^{13} \mathrm{C}_{\text {inorg }}$ is calculated as $\delta^{13} \mathrm{C}_{\mathrm{DIC}}+1$ (Romanek et al., 1992); hence, $\delta^{13} \mathrm{C}_{\text {inorg }}$ has a constant value of $+1 \%$ expressed in the $\delta^{13} \mathrm{C}_{\mathrm{c}}-\delta^{13} \mathrm{C}_{\text {DIC }}$ referential.

\section{Results}

\subsection{Modern-day dissolved inorganic carbon concentration ( $\sim 2 \mathrm{mmol} \mathrm{kg}^{-1}$ of DIC)}

\subsubsection{Growth rates and coccosphere sizes}

Cell division rates at pre-industrial DIC levels $\left(\sim 2 \mathrm{mmol} \mathrm{kg}^{-1}\right)$ are similar to those found in the published literature (Langer et al., 2006, 2009; Rickaby et al., 2010; Bach et al., 2013; Candelier et al., 2013; Hermoso et al., 2014; Kottmeier et al., 2014; Sett et al., 2014). Emiliania huxleyi is the fastest grower for the smaller cell size, achieving about one division per day $\left(\mu \sim 0.7 \mathrm{day}^{-1}\right)$ (Fig. 1a, b). The largest cells of $C$. pelagicus and P. placolithoides (19 and $16 \mu \mathrm{m}$ diameter on average, respectively) show specific growth rates around $0.5 \mathrm{day}^{-1}$. Calcidiscus leptoporus

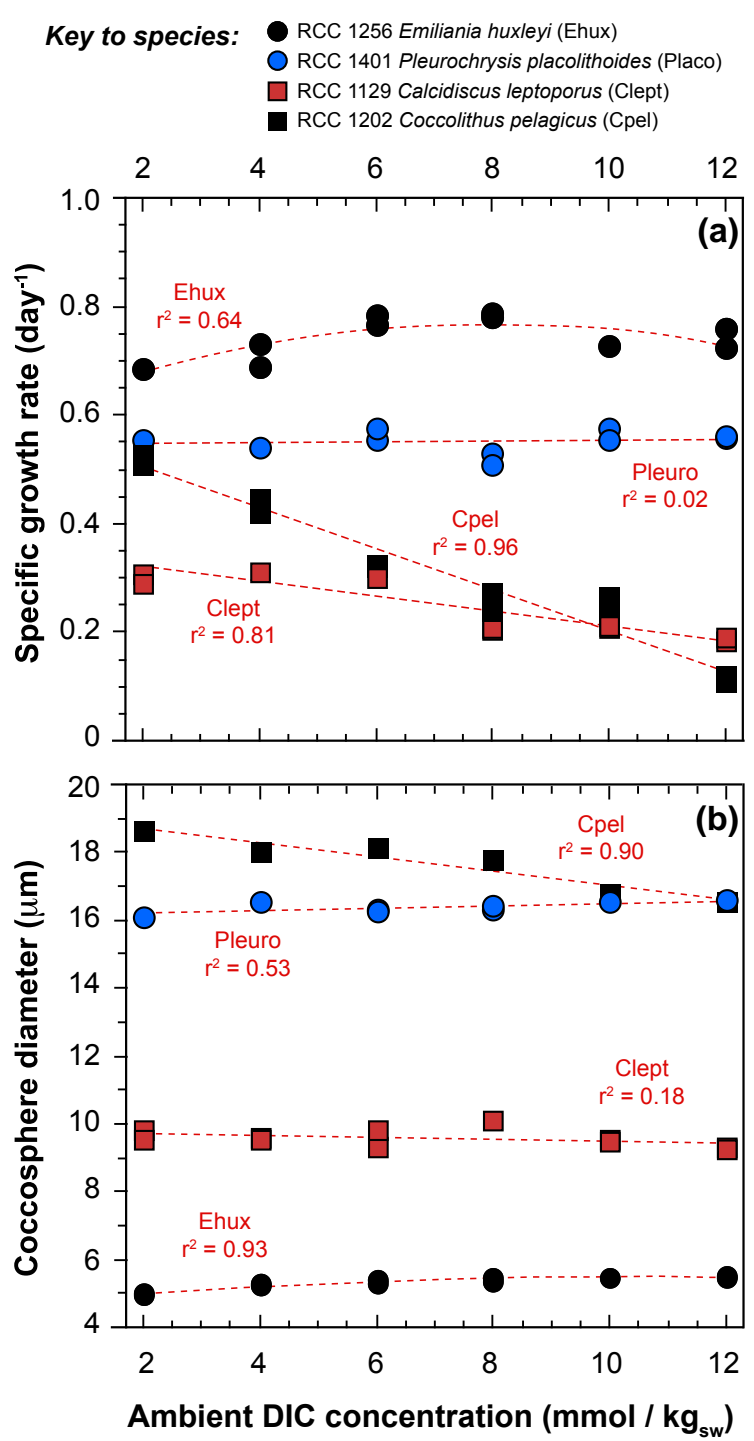

Figure 1. Changes in algae specific growth rates (a) and coccosphere diameter (b) on a range of 2 to $12 \mathrm{mmol} \mathrm{kg}^{-1}$ of DIC per kg of seawater in the culture medium. Key for species is inset at the top of the figure.

with a coccosphere diameter between $E$. huxleyi and $P$. placolithoides $(\sim 10 \mu \mathrm{m})$ exhibits the lowest division rates among all examined species at $2 \mathrm{mmol} \mathrm{kg}^{-1}$ of DIC, with $\mu$ values around 0.3 day $^{-1}$ (Fig. 1a, b).

\subsubsection{Carbon isotope composition of coccolith calcite}

The interspecies range in coccolith $\delta^{13} \mathrm{C}_{\mathrm{c}}$ values grown under preindustrial $\mathrm{CO}_{2}$ levels $\left(\sim 270 \mathrm{ppm} \sim 2 \mathrm{mmol} \mathrm{kg}^{-1}\right.$ of DIC $)$ is considerable, of the order of $3 \%$ (Fig. 2a). This variation confirms the presence of very large vital effects for the carbon isotope system (Ziveri et al., 2003; Rickaby et al., 2010; Hermoso et al., 2014). Coccolith calcite carbon isotopic compositions are distributed either side of the inorganic reference 


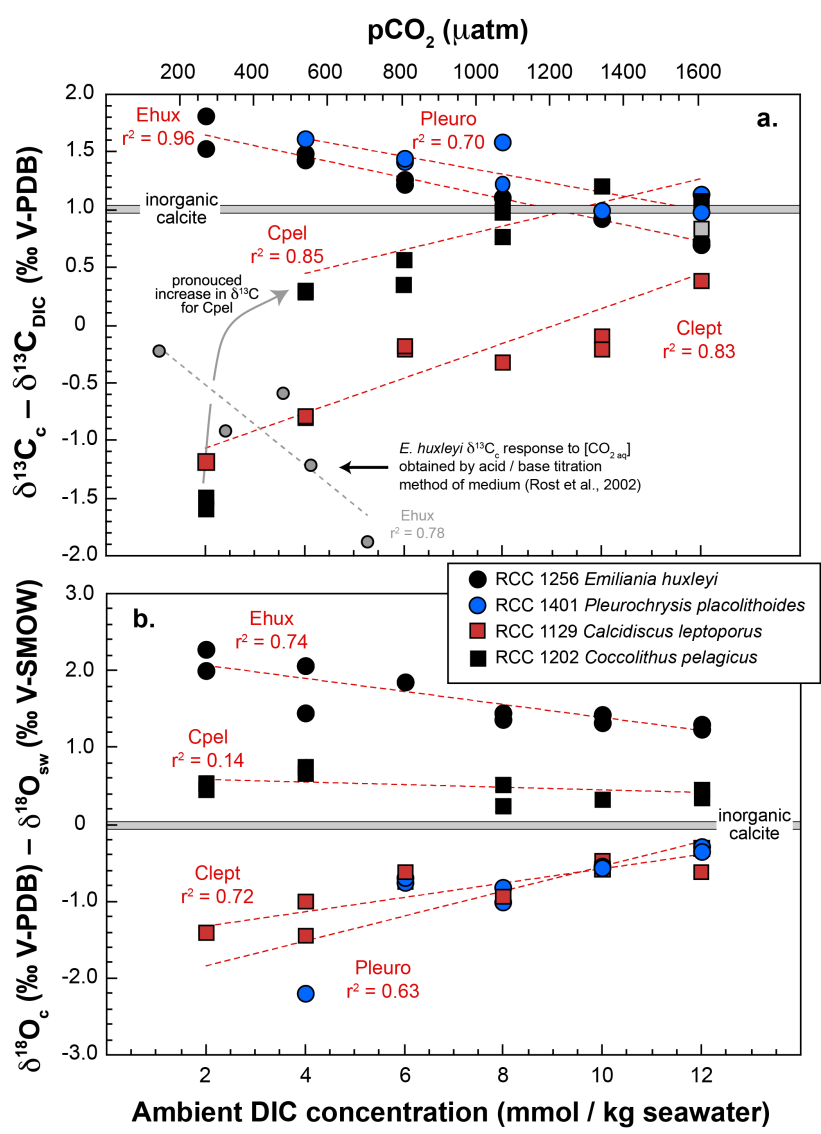

Figure 2. Changes in coccolith (a) carbon and (b) oxygen isotopes with DIC addition in the culture medium. The results are expressed by isotopic offset of coccolith composition from $\delta^{13} \mathrm{C}_{\mathrm{DIC}}$ for carbon (a) and from medium $\delta^{18} \mathrm{O}_{\mathrm{sw}}$ for oxygen (b). Inorganic calcite references as materialised by the grey horizontal bars on the graphs are calculated according to the equation given by Romanek et al. (1992) and Kim and O'Neil et al. (1997) for carbon and oxygen isotopes, respectively. Correspondence between DIC concentrations and $p \mathrm{CO}_{2}$ levels were obtained via the $\mathrm{CO} 2 \mathrm{Calc}$ software (Table 1). Legend for species is inset. For comparison with previous studies, the grey circles indicate the $\delta^{13} \mathrm{C}_{\mathrm{c}}-\delta^{13} \mathrm{C}_{\mathrm{DIC}}$ values for E. huxleyi grown by Rost et al. (2002) - work in which targeted $\left[\mathrm{CO}_{2} \mathrm{aq}\right]$ were obtained by the titration method (hence $\mathrm{pH}$ was left variable between 7.9 and 8.6). Note that only the $p \mathrm{CO}_{2}$ scale on top of the graph applies for these datapoints.

value (Fig. 2a): E. huxleyi and P. placolithoides exhibit positive $\delta^{13} \mathrm{C}$ values (hence, a "positive" ${ }^{13} \mathrm{C}$ vital effect). Due to insufficient calcite yield at harvest for isotopic analysis for P. placolithoides grown at $2 \mathrm{mmol} \mathrm{kg}^{-1}$ of DIC, the assignment of $P$. placolithoides to an isotopic "heavy group" (sensu Dudley et al., 1986) is inferred by extrapolation from the 4$12 \mathrm{mmol} \mathrm{kg}^{-1}$ range. C. pelagicus and C. leptoporus meanwhile have relatively similar $\delta^{13} \mathrm{C}_{\mathrm{c}}-\delta^{13} \mathrm{C}_{\text {inorg }}$ values, corresponding to a $-2.5 \%$ vital effect. Overall, these numbers are in good agreement with the published literature when cultures were grown at low cell concentration (see synthe- sis in Hermoso, 2014). However, substantial differences in the carbon isotope fractionation of $E$. huxleyi are apparent between the data reported here and in the work by Rost et al. (2002) (Fig. 2a). It is worth noting that different methodologies were applied to manipulate the carbonate chemistry of the media. In the present study, [DIC] and $\left[\mathrm{CO}_{2} \mathrm{aq}\right]$ linearly covary, whereas in the work by Rost et al. (2002), [DIC] was constant, but the $\mathrm{pH}$ values of each batch were different (7.9-8.6), hence suggesting a combined $\mathrm{CO}_{2}$ availabity and $\mathrm{pH}$ effect on coccolith $\delta^{13} \mathrm{C}$ values. The same study also revealed a modulation of the ${ }^{13} \mathrm{C}$ vital effect operated by the intensity of light irradiance and by the photoperiod.

\subsubsection{Oxygen isotope composition of coccolith calcite}

The $\delta^{18} \mathrm{O}$ of coccolith calcite grown by algae exposed to $2 \mathrm{mmol} \mathrm{kg}{ }^{-1}$ of DIC is also comparable to values reported in the literature with media aerated with laboratory air (Ziveri et al., 2003; Candelier et al., 2013; Hermoso et al., 2014; Stevenson et al., 2014) (Fig. 2b). Our data are thus compatible with the assignment of coccolith species into three groups on the merit of oxygen isotope composition either from $\delta^{18} \mathrm{O}_{\mathrm{c}}-\delta^{18} \mathrm{O}_{\mathrm{sw}}$ or from $\delta^{18} \mathrm{O}_{\mathrm{c}}-\delta^{18} \mathrm{O}_{\text {inorg }}$ values (the latter being used to quantify the magnitude of the "vital effect"; Eq. 2). Emiliania huxleyi ("heavy group") has the most positive $\delta^{18} \mathrm{O}_{c}$ values and large vital effects $(+2 \%$ ) (Fig. 2b). Coccolithus pelagicus ("equilibrium group") produces calcite with oxygen isotope composition close to that of inorganic calcite, although in the present study, the values are slightly $(\sim 0.5 \%$ o $)$ shifted towards relatively high $\delta^{18} \mathrm{O}$ ratios. Calcidiscus leptoporus ("light group") exhibits lower $\delta^{18} \mathrm{O}_{\mathrm{c}}$ values than the inorganic reference (Fig. 2b). The offset from inorganic calcite is $-1.4 \%$ for $C$. leptoporus, the same magnitude of the vital effect reported by Candelier et al. (2013) rather than those by Dudley et al. (1986). By extrapolation from higher DIC levels in the amended medium, it can be deduced that $P$. placolithoides would belong to the "light group", which is consistent with the work of Dudley et al. (1986) concerning the closely related species Pleurochrysis carterae.

\subsection{Effect of increased DIC (at constant $\mathrm{pH}$ ) on growth and isotopes (4-12 mmol kg-1 of DIC)}

\subsubsection{Change in cell size and growth rate with increased DIC}

Contrasting responses among examined species are observed in the evolution of specific growth rates and coccosphere volume with increased ambient DIC level, and as a result, in the carbon resource around the cells (Fig. 1a, b). The relatively fast-growing $E$. huxleyi species exhibits fertilisation (higher growth rates) from 2 to $8 \mathrm{mmol} \mathrm{kg}^{-1}$, beyond which a decrease is observed at the highest DIC levels. A similar decrease at high alkalinity was previously observed on the 
close relative Gephyrocapsa oceanica (Rickaby et al., 2010). Both $C$. leptoporus and C. pelagicus decreased cellular division rates over the 2 to $12 \mathrm{mmol} \mathrm{kg}^{-1}$ range of DIC concentration, but decreased growth rates are marked for $C$. pelagicus, with $\mu$ linearly changing from 0.5 down to 0.1 day $^{-1}$ with increasing DIC concentrations. Changing ambient DIC does not induce significant modulation of growth rate for the species $P$. placolithoides. One may expect decreased $\mu$ to be accompanied by longer generation time, and hence larger cell sizes (Aloisi, 2015). However, there is no covariation between growth rates and coccosphere and cell sizes for the species examined here (Fig. 1a, b). Nevertheless, the data confirm that both E. huxleyi and P. placolithoides cells become relatively larger with elevated DIC levels, as observed for the former in the work by Müller et al. (2012). Calcidiscus leptoporus exhibits no change in size with DIC availability, whereas $C$. pelagicus shows significantly decreased coccospheres sizes at high DIC levels.

\subsubsection{Change in carbon isotope composition of coccolith calcite}

With increased DIC concentration in the culture medium, species that exhibited high $\delta^{13} \mathrm{C}$ values at $2 \mathrm{mmol} \mathrm{kg}^{-1}$ of DIC show a significant decrease in $\delta^{13} \mathrm{C}_{\mathrm{c}}-\delta^{13} \mathrm{C}_{\text {DIC }}$ values, and hence a diminished vital effect (Fig. 2a). The observed decreases in $\delta^{13} \mathrm{C}_{\mathrm{c}}-\delta^{13} \mathrm{C}_{\text {DIC }}$ with increasing DIC are linear ( $r^{2}=0.96$ for $E$. huxleyi and 0.70 for P. placolithoides). At the highest DIC concentrations, it appears that the averages between the two duplicates show coccolith calcite $\delta^{13} \mathrm{C}_{\mathrm{c}}$ values for these two species indistinguishable from that of the inorganic reference (sensu Romanek et al., 1992); hence, vital effects vanish at high DIC. By contrast, species with lowest $\delta^{13} \mathrm{C}$ at $2 \mathrm{mmol} \mathrm{kg}^{-1}$ (C. pelagicus and C. leptoporus) show increased carbon isotope compositions with addition of DIC in the medium, a trend that also corresponds to a strong decrease in the expression of the vital effect for these species (Fig. 2a). This positive evolution is linear for C. leptoporus $\left(r^{2}=0.83\right)$ and $C$. pelagicus $\left(r^{2}=0.85\right)$, although for the latter largest species the $2 \mathrm{mmol} \mathrm{kg}^{-1}$ datapoints depart from the $4-12 \mathrm{mmol} \mathrm{kg}^{-1}$ linear trend with substantial low $\delta^{13} \mathrm{C}$ values. This "jump" in C. pelagicus $\delta^{13} \mathrm{C}$ values between 2 and $4 \mathrm{mmol} \mathrm{kg}^{-1}$ represents most of the evolution in the $\delta^{13} \mathrm{C}$ composition over the whole range of DIC concentration investigated here. At the highest DIC concentration, C. pelagicus exhibits near inorganic $\delta^{13} \mathrm{C}$ values, whereas $C$. leptoporus remains $-0.4 \%$ negatively shifted from this reference.

\subsubsection{Change in oxygen isotope composition of coccolith calcite}

The typology of a heavy and light isotopic group for the oxygen isotope system still exists with increased ambient DIC concentration, but the magnitude of the vital effect is con- siderably reduced with coccolith $\delta^{18} \mathrm{O}_{\mathrm{c}}$ tending towards inorganic values over the 2 to $12 \mathrm{mmol} \mathrm{kg}^{-1}$ of DIC range. Not only are interspecies ${ }^{18} \mathrm{O}$ vital effects reduced at high DIC, but also as is the case for carbon isotopes, the absolute vital effects become significantly reduced at the highest DIC level (Fig. 2b). There is, however, a residual $+1.3 \% \circ \delta^{18} \mathrm{O}$ shift for E. huxleyi at $12 \mathrm{mmol} \mathrm{kg}^{-1}$ of DIC, yet representing a substantial decrease in the magnitude of the vital effect compared to the $2 \mathrm{mmol} \mathrm{kg}^{-1}$ measurement. The large species C. pelagicus, assigned to a near-inorganic (sensu Kim and O'Neil, 1997) group shows constant $\delta^{18} \mathrm{O}$ values with a limited vital effect $(+0.45 \%)$, regardless of changes in ambient DIC concentrations.

\section{Discussion}

\subsection{Nature of observed isotopic changes: inorganic or vital effect?}

In biological systems, an increase in the DIC concentration of the ambient medium may not be linearly related to that of the mineralising fluid due to the effects of physiology (vital effect). The observation of such contrasting interspecific responses in $\mu, \delta^{13} \mathrm{C}$ and $\delta^{18} \mathrm{O}$ with increased DIC levels in different species points towards a biological control. That the light group increases and the heavy group decreases coccolith $\delta^{13} \mathrm{C}$ and $\delta^{18} \mathrm{O}$ values precludes a unified thermodynamic mechanism, as the directions of isotopic changes with increased DIC are opposite (Fig. 2a, b). Likewise, we cannot explain the isotopic data of coccoliths by a shift in the relative assimilation of $\mathrm{HCO}_{3}^{-}$and $\mathrm{CO}_{2}$ by the cells with changing ambient DIC concentration (Kottmeier et al., 2014).

Theoretical work and experiments seeking to identify the control of inorganic calcite isotopes have provided useful reference points that are valuable to understand biogeochemical signals and the magnitude of the vital effect. For the carbon isotope system, calcite $\delta^{13} \mathrm{C}$ composition is insensitive to temperature, precipitation rates and geologically relevant seawater $\mathrm{pH}$ values (Romanek et al., 1992). Thermodynamically, the mechanisms and the dynamics of oxygen isotope fractionation are very different to those for the carbon isotopes (Zeebe and Wolf-Gladrow, 2001). Large isotopic kinetic effects are documented with high precipitation rates favouring ${ }^{16} \mathrm{O}$ incorporation into the calcite crystal (Gabitov et al., 2012). This effect can be as high as $1.5 \%$ for $\delta^{18} \mathrm{O}$ values, and corresponds to the "kinetic limit" by Watkins et al. (2013, 2014). An understanding of the saturation state with respect to calcite in the coccolith vesicle, and of true calcite precipitation rates, is currently lacking. Both of these concepts are relevant for understanding the vital effect.

The present data set is not sufficient to tackle whether coccolithophore calcite isotopically derives from $\mathrm{a} \mathrm{CO}_{2}$ or a $\mathrm{HCO}_{3}^{-}$source, as it would have required measurement of coeval $\delta^{13} \mathrm{C}_{\text {org }}$ values. Current literature points towards a mixture of these two DIC species for calcification (e.g. Kottmeier 
et al., 2014). In the following account, we develop an empirical approach on stable isotopes in coccoliths. Our primary aim here is to better interpret fossil coccolith isotopic signals in the context of DIC availability in the past, without making a hypothesis on which DIC species is used.

\subsection{From carbon availability for the cell to the expression of vital effect}

\subsubsection{Carbon isotope system}

In photosynthetic, or photosynthetic-associated biomineralisers such as the foraminifera, corals and coccolithophores, a ${ }^{12} \mathrm{C}$-DIC depletion of the internal carbon pool due to photosynthetic fractionation by the enzyme Ribulose-1,5bisphosphate carboxylase/oxygenase (RuBisCO) may imprint the whole internal carbon pool $(\mathrm{Ci})$, leading to substantial isotopic consequences for the stable isotope composition of biominerals (McConnaughey, 1989; Spero et al., 1997; Hermoso et al., 2014).

The species E. huxleyi and P. placolithoides show particularly high calcite $\delta^{13} \mathrm{C}$ values, isotopically higher than both the possible $\mathrm{HCO}_{3}^{-}$and $\mathrm{CO}_{2}$ aq sources (for reference: $\Delta{ }^{13} \mathrm{C}_{\mathrm{CO} 2}$ aq-HCO3$-\sim 9 \%$ and $\Delta \Delta^{13} \mathrm{C}_{\text {calcite- }}-\mathrm{HCO}_{3}-\sim 1 \%$ o at $15^{\circ} \mathrm{C}$; Zeebe and Wolf-Gladrow, 2001). By contrast, C. pelagicus and C. leptoporus have lower carbon isotopic composition at the preindustrial $\left(2 \mathrm{mmol} \mathrm{kg}^{-1}\right)$ DIC level, falling between $\delta^{13} \mathrm{C}$ of $\mathrm{CO}_{2}$ aq and $\delta^{13} \mathrm{C}$ of $\mathrm{HCO}_{3}^{-}$, hence with a lower carbon isotope composition than the inorganic calcite (Fig. 2a).

In species characterised by low PIC / POC, typically $E$. huxleyi, the internal DIC pool is isotopically offset towards high $\delta^{13} \mathrm{C}$ values due to intense preferential ${ }^{12} \mathrm{C}$ fixation by photosynthesis (Laws et al., 2002; Benthien et al., 2007; Hermoso et al., 2014; Tchernov et al., 2014). In the culture experiments on E. huxleyi by Bach et al. (2013), PIC / POC ratios increased in response to increasing [DIC], which was explained by a decrease in the production of POC. Thus, the lowered E. huxleyi $\delta^{13} \mathrm{C}$ measured at high DIC concentrations in the present study are the likely consequence of the internal carbon pool becoming less imprinted by ${ }^{12} \mathrm{C}$ photosynthetic-driven Rayleigh fractionation because the latter process is "diluted" in a larger internal carbon pool. We must note, however, that there are substantial discrepancies in the reported $\delta^{13} \mathrm{C}_{\mathrm{c}}-\delta^{13} \mathrm{C}_{\text {DIC }}$ values for $E$. huxleyi between the present study and that by Rost et al. (2002) (Fig. 2a). These differences can be tentatively assigned to divergences in the experimental set-up, such as a combined effect of $\left[\mathrm{CO}_{2 \mathrm{aq}}\right]$ and $\mathrm{pH}$ in the data set by Rost et al. (2002), pointing towards a more complex control on the expression of the vital effect than that exerted merely by $\mathrm{CO}_{2}$ availability.

Species originally with very high $\delta^{13} \mathrm{C}$ values at $2 \mathrm{mmol} \mathrm{kg}{ }^{-1}$ of DIC show a clear increase in their coccolith carbon isotopic ratios with increasing DIC. The increase in C. leptoporus and C. pelagicus $\delta^{13} \mathrm{C}$ with increased DIC is well-correlated with DIC concentrations (Fig. 2a). It is surprising to observe a clear decrease in specific growth rates of C. leptoporus and C. pelagicus with more carbon resource in the medium. It has been suggested that intense calcification in C. pelagicus may impair growth under high DIC levels due to the challenge to translocate protons outside the cells (Rickaby et al., 2010; Hermoso, 2015). The explanation for higher $\delta^{13} \mathrm{C}$ values of $C$. leptoporus and C. pelagicus is likely to be common, as with more DIC, a decrease in the PIC / POC ratio is observed in both species (Rickaby et al., 2010; Langer and Bode, 2011; Bach et al., 2013; Diner et al., 2015). With enhanced organic carbon fixation over calcification (i.e. decreased PIC / POC), the whole cell carbon isotopic inventory may become more imprinted by photosynthetic ${ }^{12} \mathrm{C}$ depletion, and as a result, both species produce coccoliths exhibiting isotopically higher carbon isotope signatures, an opposite trend to that observed for E. huxleyi.

\subsubsection{Oxygen isotope system}

It has been hypothesised that the isotopic heavy group is an isotopic relic of a partial $\mathrm{CO}_{2}$ assimilation by coccolithophore cells (Hermoso et al., 2014). Indeed, $\mathrm{CO}_{2}$ bears excess ${ }^{18} \mathrm{O}$ atoms compared to $\mathrm{DIC}$ and $\mathrm{HCO}_{3}^{-}$; the isotopic composition used to compute that of equilibrium calcite (Kim and O'Neil, 1997; Bemis et al. 1998; Zeebe and Wolf-Gladrow, 2001). The fraction of the DIC influx to the cell entering in the form of $\mathrm{HCO}_{3}^{-}$does not induce any ${ }^{18} \mathrm{O}$ enrichment of the $\mathrm{Ci}\left(\Delta^{18} \mathrm{O}_{\mathrm{CO} 2 \text { aq-HCO}}-=23.6 \%\right.$; Zeebe and Wolf-Gladrow, 2001), as the oxygen isotopic composition of inorganic calcite is primarily computed from $\delta^{18} \mathrm{O}$ of $\mathrm{HCO}_{3}^{-}$(Kim and O'Neil, 1997; Zeebe and Wolf-Gladrow, 2001). Without other thermodynamic effects, a mere acquisition of $\mathrm{HCO}_{3}^{-}$by the cell would correspond to equilibrium values. We must add that due to the complexity of the kinetics of the oxygen isotope system, it is, however, impossible to use coccolith $\delta^{18} \mathrm{O}$ to quantify the relative supply of DIC by aqueous $\mathrm{CO}_{2}$ and bicarbonate ions.

Under low ambient DIC levels and consecutive carbonlimited conditions, there may be a fast turnover of the internal carbon pool (Nimer et al., 1992), which allows less time between $\mathrm{CO}_{2}$ assimilation and calcification in the coccolith vesicle. The residence time of the fraction of the $\mathrm{Ci}$ built from assimilation of aqueous $\mathrm{CO}_{2}$ to calcification is fundamental for the extent to which this ${ }^{18} \mathrm{O}$-rich carbon influx is registered by the coccolith calcite, as it tends to be erased due to isotopic exchange between DIC and $\mathrm{H}_{2} \mathrm{O}$ molecules. In a fast-growing (calcifying) species, the ${ }^{18} \mathrm{O}$ excess borne by the $C i$ is less isotopically re-equilibrated, and leads to relatively high $\delta^{18} \mathrm{O}$ values in coccoliths compared to inorganic calcite or slow growers such as $C$. pelagicus.

In the present study, in all species except $C$. pelagicus that always displays near-inorganic $\delta^{18} \mathrm{O}$ values, a link between [DIC] and $\delta^{18} \mathrm{O}$ values confirms that the ${ }^{18} \mathrm{O}$ vital effect may be related to the overturning rate (or the "demand-to-supply" 
ratio; see Bolton and Stoll, 2013). The corresponding isotopic relevant process for the oxygen isotope system is the residence time of the internal carbon pool from cell assimilation of carbon resource to calcification. In E. huxleyi with increasing DIC, the record of this ${ }^{18} \mathrm{O}$ excess vanishes, implying that the intracellular residence time of the DIC species in the carbon pool must increase with DIC availability, therefore diminishing the isotopic offset. Comparing our isotope data for E. huxleyi and those for G. oceanica by Rickaby et al. (2010), we observe that there seems to be an isotopic continuum between the two species based on their isotopic composition-[DIC] relationship (Fig. 3).

For $C$. pelagicus, possible changes in the residence time of the carbon pool prior to its partial mineralisation does not induce expression of an ${ }^{18} \mathrm{O}$ vital effect (Fig. 2b). Nearequilibrium composition of $C$. pelagicus calcite was consistently found under changing temperature and $\mathrm{pH}$ conditions (Stevenson et al., 2014; Hermoso, 2015). The expression of a very limited ${ }^{18} \mathrm{O}$ vital effect, likely due to the completeness of the oxygen isotope DIC- $\mathrm{H}_{2} \mathrm{O}$ exchange at the time of calcification in this relatively slow growing species (Hermoso et al., 2014), is a fundamentally important observation with respect to palaeoclimate studies in deep time, due to the geological importance of this near "vital effect-free" species that can be used as a reference.

With this biogeochemical control of oxygen isotope fractionation in coccolith calcite in mind, it remains difficult to explain the lower magnitude of the ${ }^{18} \mathrm{O}$ vital effect for the isotopic "light group" (C. leptoporus and P. placolithoides). That higher coccolith $\delta^{18} \mathrm{O}$ values are recorded with higher ${ }^{18} \mathrm{O}$-rich $\mathrm{CO}_{2}$ influx may represent an intuitive reasoning, and reconcile the data. However, their $\delta^{18} \mathrm{O}$ values are "capped" by equilibrium values and do not go towards the heavy group end-member as observed in E. huxleyi or $G$. oceanica (Fig. 2b), challenging this hypothesis.

\subsection{Outlook for coccolith-based palaeoceanographic reconstructions}

Using geological evidence in the Neogene, it was reported that large coccoliths exhibit $\delta^{13} \mathrm{C}$ values similar to that of planktonic foraminifera whose composition was regarded close to the DIC composition (Bolton et al., 2012). In contrast, small coccoliths were reported to have relatively high $\delta^{13} \mathrm{C}$ values in the same study. Our culture data at relatively low DIC concentrations are compatible with these natural environment observations. Furthermore, the present culturebased study confirms the limited expression of ${ }^{13} \mathrm{C}$ vital effect at the highest DIC level (Fig. 2a). For coccolith $\delta^{18} \mathrm{O}$, the same authors found the opposite: the smallest coccoliths are closest to the foraminifera, and the bigger coccoliths show higher isotopic values. This is also in agreement with the isotopic typology of coccolith calcite, with the notable difference that in culture, larger cells such as C. pelagicus exhibit near-equilibrium composition. One possible explana-

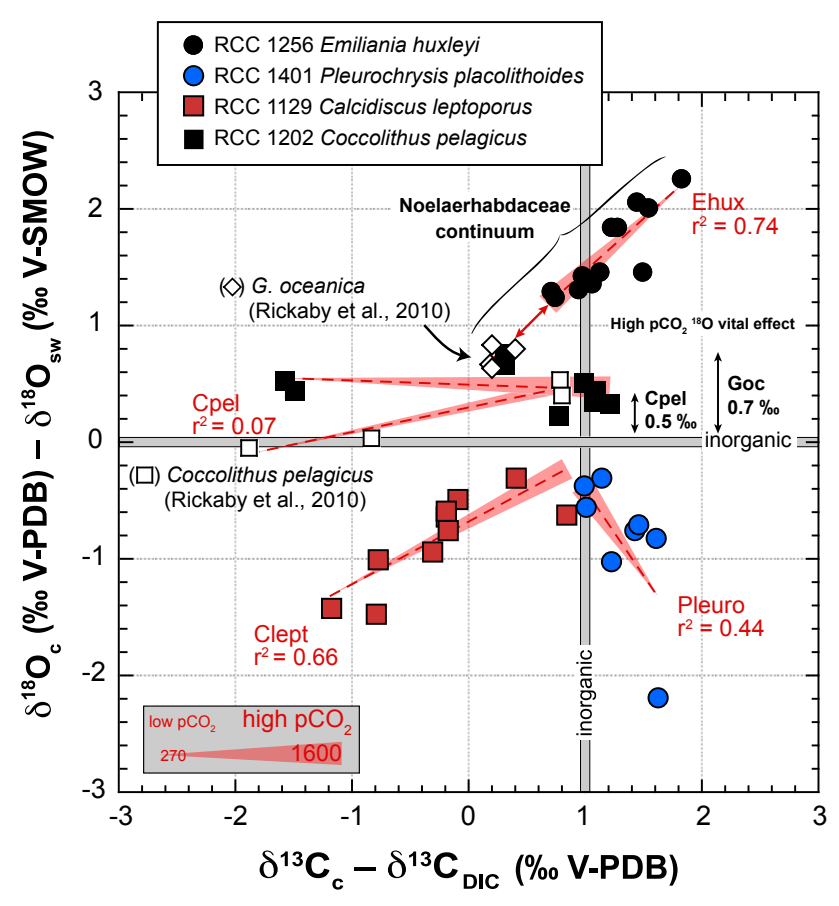

Figure 3. Scatter plot of carbon and oxygen isotopic offsets with increased DIC concentration. Superimposed on the linear regression lines, the wider side of the red triangles denotes a higher DIC level. With increased DIC and aqueous $\mathrm{CO}_{2}$ concentration in the medium, we observe a clear decrease in the magnitude of isotopic disequilibria in both carbon and oxygen systems, with coccolith isotope compositions converging towards inorganic composition. Note that a correction of $+0.64 \%$ was applied to the $\delta^{18} \mathrm{O}_{\mathrm{c}}$ values of Rickaby et al. (2010) to account for a temperature offset of $+3{ }^{\circ} \mathrm{C}$ with the culture data of the present study.

tion for this discrepancy between culture and sediment data may be the exacerbation of the vital effect in culture due to highly fertilising growth conditions of coccolithophores exposed to high light and nutrient levels (Hermoso et al., 2015). Although the present culture data can be regarded as robust, based on reproducibility of growth and isotope composition in replicated bioassays and thanks to the very dilute cultures undertaken, other carefully conducted studies have reported significantly different carbon isotope fractionation values for E. huxleyi using another methodology than that implemented in the present study (Rost et al., 2002; Fig. 2a). This discrepancy highlights that carbon availability cannot be considered as the only driving parameter dictating the magnitude of the vital effects in coccolith calcite. Further experimental work is required to deconvolve the effects of the intricate mechanisms governing them, and ultimately to account for changes in seawater carbonate chemistry as they occur in the "real" oceans. On a similar note, we should stress the importance of considering the whole set of environment parameters, as in our study case, light, nutrient and DIC conditions were likely replete with respect to the natural environment. Under the as- 
sumption that in culture, growth rate reached their maxima, it would appear that in the natural environment growth rates were lower, and as a consequence, the vital effects, especially for the oxygen isotopes, were also lower.

Using our empirical calibration between the magnitude of the vital effect with DIC concentration or with equivalent $p \mathrm{CO}_{2}$ (Figs. 2a, $\mathrm{b}$ and 3), we validate and encourage the use of coccolith monotaxic to infer SST estimates. The present study indicates that reconstructing meaningful SST estimates from coccolith calcite (and hence, bulk carbonate) $\delta^{18} \mathrm{O}$ values requires the a priori knowledge of the range of $p \mathrm{CO}_{2}$ concentrations for the considered time interval. Furthermore, the data indicate that a constant coefficient of the vital effect cannot homogenously be applied to a coccolith species over its entire geological existence, with the notable exception of Coccolithus pelagicus. For this species, a unique correction of the ${ }^{18} \mathrm{O}$ vital effect of $0.5 \%$ can be applied to $\delta^{18} \mathrm{O}_{\mathrm{c}}$ values to reconstruct SSTs under relatively elevated $p \mathrm{CO}_{2}$ levels, typically over $600 \mathrm{ppm}$. Furthermore, it is worth noting that the magnitude of this biological fractionation does not change with $\mathrm{pH}$ in this species (Hermoso, 2015). In the data set of Rickaby et al. (2010), the reported coefficient of the vital effect is the same for $C$. pelagicus at high DIC as in the present study, and for G. oceanica, it is $0.7 \%$ obove a 600 ppm threshold.

Exploiting interspecies signals, such as the large-small coccolith isotopic offset proposed by Bolton et al. (2012), has the notable advantage of circumventing uncertainties that complicate palaeoceanographic reconstructions (salinity, temperature, seawater $\delta^{18} \mathrm{O}$ ), as they are cancelled out, as they have, at least to first order, a similar effect on coccolith calcite composition. Indeed, considering the arguments presented in this study showing a control by ambient carbon availability and growth dynamics, it appears that the magnitude of the vital effect contains an important environmental parameter sought in palaeoceanography, namely DIC concentrations. Interspecies $\Delta \delta^{18} \mathrm{O}$ and $\Delta \delta^{13} \mathrm{C}$ offsets with [DIC] can be calculated in the context of the investigated geological period using the data from the present work or those in Rickaby et al. (2010).

The hypothesis by Bolton and Stoll (2013) about a possible "Late Miocene threshold" at about $375-575 \mathrm{ppm}$ of atmospheric of $\mathrm{CO}_{2}$ is expressed in our data set by a big "jump" in $\delta^{13} \mathrm{C}$ value for Coccolithus pelagicus (not seen in $\delta^{18} \mathrm{O}$ values). In high DIC (elevated atmospheric $\mathrm{CO}_{2}$ ) regimes of ocean history with vanished vital effects, departures from the unified $+1 \%$ in $\delta^{13} \mathrm{C}_{\mathrm{c}}-\delta^{13} \mathrm{C}$ values that can be reconstructed with paired coccolith-foraminifera measurements can be used as a proxy for photosynthetic activity in coccolithophores. This approach could complement alkenone-derived palaeo- $\mathrm{CO}_{2}$ estimates by significantly contribute constraining seawater $\delta^{13} \mathrm{C}_{\mathrm{CO}_{2}}$ composition and the so-called " $b$ " coefficient (Pagani, 2002; Pagani et al., 2005). This novel approach (recently outlined in Hermoso, 2015, and Hermoso et al., 2015) will require coupled foraminiferal data that may serve as an inorganic reference (Spero et al., 2003). In addition, it appears possible to reconstruct cell geometry via morphometric measurements made on fossil coccoliths (Henderiks and Rickaby, 2007; Henderiks, 2008; Henderiks and Pagani, 2008), as this parameter is of paramount importance for inferring algal growth dynamics and cell size in the absence of preserved coccospheres in the sedimentary register, except in some peculiar settings (Gibbs et al., 2013).

\section{Conclusions}

This work provides new constraints on the "mobilis in mobili" nature of the vital effect in coccolith calcite (Hermoso, 2014). We show that the turnover of carbon and differences in growth rates and potentially relative allocation of the internal pool to photosynthesis and calcification (PIC / POC) concurrently set the magnitude of the vital effect in both carbon and oxygen isotope systems. In coccolithophores, the expression of the vital effect is stronger with a small internal carbon reservoir induced by relatively low ambient carbon concentrations typical of the modern oceans compared to the $p \mathrm{CO}_{2}$ Neogene history. Several lines of evidence now point towards a reduced, if not absent, vital effect under high $\mathrm{CO}_{2}$ levels, as prevailed during most of the Meso-Cenozoic. Therefore, the assumption that downcore coccolith $\delta^{18} \mathrm{O}$ can be transferred into SST estimates using the equations outlined in Kim and O'Neil (1997) or more recently in Watkins et al. (2013) becomes practical when studying deep time intervals. Due to the complex physiological and environmental control on isotopes in coccolithophores, a fully quantitative modelling approach is now essential, in particular to trace which DIC species are used from the external environment to the coccolith vesicle, and thus refine our understanding of the precise mechanisms behind the vital effect.

Since the pioneering studies on coccolith geochemistry in the 1980s (Anderson and Steinmetz, 1981; Steinmetz and Anderson, 1984; Dudley et al., 1986), a growing body of literature highlights the potential for application to palaeoceanography. Recent work shows major steps towards a complete understanding of the vital effect imprinting isotopes of coccolith calcite based on biogeochemistry and physiology, which may "rival" our quantitative understanding of foraminiferal proxies. These studies and the present work point towards the possibility of generating coccolith-derived long-term SST reconstruction and/or $p \mathrm{CO}_{2}$ levels during periods of abrupt climate change, such as the PETM, Cenozoic climate optima or Mesozoic OAEs.

Acknowledgements. The laboratory work presented in this paper was mostly undertaken by I. Z. X. Chan, as part of his Master's research project in 2013 under the main supervision and guidance of M. Hermoso. We thank C. Day for help with the isotopic analyses in Oxford and Phil Renforth for seawater alkalinity measurements. We are also grateful to J. Rolfe at Cambridge University for his dili- 
gence in running carbon isotope analyses of the seawater batches. The authors thank J. Bijma for editorial handling, and L.-M. Holtz and two other anonymous referees for comments on the discussion paper that have substantially improved the final version of the manuscript. This work was supported by the European Research Council (grant SP2-GA-2008-200915) to R. E. M. Rickaby and by the Natural Environment Research Council (grant NE/H015523/1) to $\mathrm{M}$. Hermoso. The article processing charges of this paper have been covered by the OpenAIRE programme.

Edited by: J. Bijma

\section{References}

Aloisi, G.: Covariation of metabolic rates and cell size in coccolithophores, Biogeosciences, 12, 4665-4692, doi:10.5194/bg-124665-2015, 2015.

Anderson, T. F. and Steinmetz, J. C.: Isotopic and biostratigraphical records of calcareous nannofossils in a Pleistocene core, Nature, 294, 741-744, doi:10.1038/294741a0, 1981.

Bach, L. T., Mackinder, L. C. M., Schulz, K. G., Wheeler, G., Schroeder, D. C., Brownlee, C., and Riebesell, U.: Dissecting the impact of $\mathrm{CO}_{2}$ and $\mathrm{pH}$ on the mechanisms of photosynthesis and calcification in the coccolithophore Emiliania huxleyi, New Phytol., 199, 121-134, 2013.

Barry, J. P., Hall-Spencer, J. M., and Tyrell, T.: In situ perturbation experiments: natural venting sites, spatial/temporal gradients in ocean $\mathrm{pH}$, manipulative in situ $p \mathrm{CO}_{2}$ perturbations, in Guide to Best Practices for Ocean Acidification Research and Data Reporting, edited by: Riebesell, U., Fabry, V. J., Hansson, L., and Gatuso, J. P., Publications Office of the European Union, Luxembourg, 123-136, 2010.

Bemis, B. E., Spero, H. J., Bijma, J., and Lea, D. W.: Reevaluation of the oxygen isotopic composition of planktonic foraminifera: Experimental results and revised paleotemperature equations, Paleoceanography, 13, 150-160, doi:10.1029/98PA00070, 1998.

Benthien, A., Zondervan, I., Engel, A., Hefter, J., Terbrüggen, A., and Riebesell, U.: Carbon isotopic fractionation during a mesocosm bloom experiment dominated by Emiliania huxleyi: Effects of $\mathrm{CO}_{2}$ concentration and primary production, Geochim. Cosmochim. Ac., 71, 1528-1541, 2007.

Bidigare, R. R., Fluegge, A., Freeman, K. H., Hanson, K. L., Hayes, J. M., Hollander, D., Jasper, J. P., King, L. L., Laws, E. A., Milder, J., Millero, F. J., Pancost, R., Popp, B. N., Steinberg, P. A., and Wakeham, S. G.: Consistent fractionation of ${ }^{13} \mathrm{C}$ in nature and in the laboratory: Growth-rate effects in some haptophyte algae, Global Biogeochem. Cy., 11, 279-292, 1997.

Bolton, C. T. and Stoll, H. M.: Late Miocene threshold response of marine algae to carbon dioxide limitation, Nature, 500, 558-562, 2013.

Bolton, C. T., Stoll, H. M., and Mendez-Vicente, A.: Vital effects in coccolith calcite: Cenozoic climate- $p \mathrm{CO}_{2}$ drove the diversity of carbon acquisition strategies in coccolithophores?, Paleoceanography, 27, PA4204, doi:10.1029/2012PA002339, 2012.

Bown, P.: Calcareous Nannofossil Biostratigraphy, British Micropalaeontological Society Publication Series, Kluwer Academic, London, UK, 1998.
Candelier, Y., Minoletti, F., Probert, I., and Hermoso, M.: Temperature dependence of oxygen isotope fractionation in coccolith calcite: A culture and core top calibration of the genus Calcidiscus, Geochim. Cosmochim. Ac., 100, 264-281, 2013.

De Bodt, C., Van Oostende, N., Harlay, J., Sabbe, K. and Chou, L.: Individual and interacting effects of $p \mathrm{CO}_{2}$ and temperature on Emiliania huxleyi calcification: study of the calcite production, the coccolith morphology and the coccosphere size, Biogeosciences, 7, 1401-1412, doi:10.5194/bg-7-1401-2010, 2010.

Diner, R. E., Benner, I., Passow, U., Komada, T., Carpenter, E. J., and Stillman, J. H.: Negative effects of ocean acidification on calcification vary within the coccolithophore genus Calcidiscus, Mar. Biol., doi:10.1007/s00227-015-2669-x, 2015.

Dudley, W., Blackwelder, P., Brand, L., and Duplessy, J.-C.: Stable isotopic composition of coccoliths, Mar. Micropaleontol., 10, 18, 1986.

Erez, J. and Luz, B.: Temperature control of oxygen-isotope fractionation of cultured planktonic foraminifera, Nature, 297, 220222, 1982.

Gabitov, R. I., Watson, E. B., and Sadekov, A.: Oxygen isotope fractionation between calcite and fluid as a function of growth rate and temperature: An in situ study, Chem. Geol., 306-307, 92102, 2012.

Gibbs, S. J., Poulton, A. J., Bown, P. R., Daniels, C. J., Hopkins, J., Young, J. R., Jones, H. L., Thiemann, G. J., O’Dea, S. A., and Newsam, C.: Species-specific growth response of coccolithophores to Palaeocene-Eocene environmental change, Nat. Geosci., 6, 1-5, 2013.

Grauel, A.-L., Schmid, T. W., Hu, B., Bergami, C., Capotondi, L., Zhou, L., and Bernasconi, S. M.: Calibration and application of the "clumped isotope" thermometer to foraminifera for highresolution climate reconstructions, Geochim. Cosmochim. Ac., 108, 125-140, 2013.

Henderiks, J.: Coccolithophore size rules - Reconstructing ancient cell geometry and cellular calcite quota from fossil coccoliths, Mar. Micropaleontol., 67, 143-154, 2008.

Henderiks, J. and Pagani, M.: Coccolithophore cell size and the Paleogene decline in atmospheric $\mathrm{CO}_{2}$, Earth Planet. Sc. Lett., 269, 576-584, 2008.

Henderiks, J. and Rickaby, R. E. M.: A coccolithophore concept for constraining the Cenozoic carbon cycle, Biogeosciences, 4, 323-329, doi:10.5194/bg-4-323-2007, 2007.

Hermoso, M.: Coccolith-derived isotopic proxies in palaeoceanography: where geologists need biologists, Cryptogamie Algol., 35, 323-351, doi:10.7872/crya.v35.iss4.2014.323, 2014.

Hermoso, M.: Control of ambient $\mathrm{pH}$ on growth and stable isotopes in phytoplanktonic calcifying algae, Paleoceanography, 30, 1100-1112, doi:10.1002/2015PA002844, 2015.

Hermoso, M., Horner, T. J., Minoletti, F., and Rickaby, R. E. M.: Constraints on the vital effect in coccolithophore and dinoflagellate calcite by oxygen isotopic modification of seawater, Geochim. Cosmochim. Ac., 44, 612-627, 2014.

Hermoso, M., Candelier, Y., Browning, T. J., and Minoletti, F.: Environmental control of the isotopic composition of subfossil coccolith calcite: Are laboratory culture data transferable to the natural environment?, GeoResJ, 7, 35-42, doi:10.1016/j.grj.2015.05.002, 2015. 
Holtz, L.-M., Wolf-Gladrow, D., and Thoms, S.: Numerical cell model investigating cellular carbon fluxes in Emiliania huxleyi, J. Theor. Biol., 364, 305-315, 2015.

Iglesias-Rodriguez, M. D., Halloran, P. R., Rickaby, R. E. M., Hall, I. R., Colmenero-Hidalgo, E., Gittins, J. R., Green, D. R. H., Tyrrell, T., Gibbs, S. J., von Dassow, P., Rehm, E., Armbrust, E. V., and Boessenkool, K. P.: Phytoplankton calcification in a high- $\mathrm{CO}_{2}$ world., Science, 320, 336-340, 2008.

Kim, S.-T. and O'Neil, J. R.: Equilibrium and nonequilibrium oxygen isotope effects in synthetic carbonates, Geochim. Cosmochim. Ac., 61, 3461-3475, 1997.

Kottmeier, D. M., Rokitta, S. D., Tortell, P. D., and Rost, B.: Strong shift from $\mathrm{HCO}_{3}^{-}$to $\mathrm{CO}_{2}$ uptake in Emiliania huxleyi with acidification: new approach unravels acclimation versus short-term pH effects, Photosynth. Res., 121, 265-275, doi:10.1007/s11120-014-9984-9, 2014.

Langer, G. and Bode, M.: $\mathrm{CO}_{2}$ mediation of adverse effects of seawater acidification in Calcidiscus leptoporus, Geochem. Geophy. Geosy., 12, Q05001, doi:10.1029/2010GC003393, 2011.

Langer, G., Geisen, M., Baumann, K.-H., Kläs, J., Riebesell, U., Thoms, S. and Young, J. R.: Species-specific responses of calcifying algae to changing seawater carbonate chemistry, Geochem. Geophy. Geosy., 7, Q09006, doi:10.1029/2005GC001227, 2006.

Langer, G., Nehrke, G., Probert, I., Ly, J., and Ziveri, P.: Strain-specific responses of Emiliania huxleyi to changing seawater carbonate chemistry, Biogeosciences, 6, 2637-2646, doi:10.5194/bg-6-2637-2009, 2009.

Laws, E. A., Popp, B. N., Cassar, N., and Tanimoto, J.: ${ }^{13} \mathrm{C}$ discrimination patterns in oceanic phytoplankton: likely influence of $\mathrm{CO}_{2}$ concentrating mechanisms, and implications for palaeoreconstructions, Funct. Plant Biol., 29, 323-333, 2002.

McConnaughey, T.: ${ }^{13} \mathrm{C}$ and ${ }^{18} \mathrm{O}$ isotopic disequilibrium in biological carbonates: I. Patterns, Geochim. Cosmochim. Ac., 53, 151$162,1989$.

Minoletti, F., Hermoso, M., Candelier, Y., and Probert, I.: Calibration of stable isotope composition of Thoracosphaera heimii (dinoflagellate) calcite for reconstructing paleotemperatures in the intermediate photic zone, Paleoceanography, 29, 1111-1126, doi:10.1002/2014PA002694, 2014.

Müller, M. N., Beaufort, L., Bernard, O., Pedrotti, M. L., Talec, A., and Sciandra, A.: Influence of $\mathrm{CO}_{2}$ and nitrogen limitation on the coccolith volume of Emiliania huxleyi (Haptophyta), Biogeosciences, 9, 4155-4167, doi:10.5194/bg-9-4155-2012, 2012.

Nimer, N. A, Dixon, G. K., and Merrett, M. J.: Utilization of inorganic carbon by the coccolithophorid Emiliania huxleyi (Lohmann) Kamptner, New Phytol., 120, 153-158, 1992.

Pagani, M.: The alkenone- $\mathrm{CO}_{2}$ proxy and ancient atmospheric carbon dioxide, Philos. T. Roy. Soc. A, 360, 609-632, 2002.

Pagani, M., Zachos, J. C., Freeman, K. H., Tipple, B., and Bohaty, S.: Marked decline in atmospheric carbon dioxide concentrations during the Paleogene, Science, 309, 600-603, 2005.

Rickaby, R. E. M., Henderiks, J., and Young, J. N.: Perturbing phytoplankton: response and isotopic fractionation with changing carbonate chemistry in two coccolithophore species, Clim. Past, 6, 771-785, doi:10.5194/cp-6-771-2010, 2010.

Riebesell, U., Zondervan, I., Rost, B., Tortell, P. D., Zeebe, R. E., and Morel, F. M.: Reduced calcification of marine plankton in response to increased atmospheric $\mathrm{CO}_{2}$, Nature, 407, 364-367, 2000.
Rollion-Bard, C., Chaussidon, M., and France-Lanord, C.: Biological control of internal $\mathrm{pH}$ in scleractinian corals: Implications on paleo-pH and paleo-temperature reconstructions, C. R. Geosci., 343, 397-405, 2011.

Romanek, C. S., Morse, J. W., and Grossman, E. L.: Carbon isotopic fractionation in synthetic aragonite and calcite: Effects of temperature and precipitation rate, Geochim. Cosmochim. Ac., 56, 419-430, 1992.

Rost, B., Zondervan, I., and Riebesell, U.: Light-dependent carbon isotope fractionation in the coccolithophorid Emiliania huxleyi, Limnol. Oceanogr., 47, 120-128, doi:10.4319/lo.2002.47.1.0120, 2002.

Sett, S., Bach, L. T., Schulz, K. G., Koch-Klavsen, S., Lebrato, M., and Riebesell, U.: Temperature modulates coccolithophorid sensitivity of growth, photosynthesis and calcification to increasing seawater $p \mathrm{CO}_{2}, \mathrm{PLoS}$ One, 9, e88308, doi:10.1371/journal.pone.0088308, 2014.

Spero, H. J., Bijma, J., Lea, D. W., and Bemis, B. E.: Effect of seawater carbonate concentration on foraminiferal carbon and oxygen isotopes, Nature, 390, 497-500, 1997.

Steinmetz, J. C. and Anderson, T. F.: The significance of isotopic and paleontologic results on Quaternary calcareous nannofossil assemblages from Caribbean core P6304-4, Mar. Micropaleontol., 8, 403-424, 1984.

Stevenson, E. I., Hermoso, M., Rickaby, R. E. M., Tyler, J. J., Minoletti, F., Parkinson, I. J., Mokadem, F., and Burton, K. W.: Controls on Stable strontium isotope fractionation in coccolithophores with implications for the marine Sr cycle, Geochim. Cosmochim. Ac., 128, 225-235, 2014.

Suffrian, K., Schulz, K. G., Gutowska, M. A., Riebesell, U., and Bleich, M.: Cellular pH measurements in Emiliania huxleyi reveal pronounced membrane proton permeability, New Phytol., 190, 595-608, 2011.

Tchernov, D., Gruber, D., and Irwin, A.: Isotopic fractionation of carbon in the coccolithophorid Emiliania huxleyi, Mar. Ecol.Prog. Ser., 508, 53-66, 2014.

Thierstein, H. R., Geitzenauer, K. R., Molfino, B., and Shackleton, N. J.: Global synchroneity of late Quaternary coccolith datum levels Validation by oxygen isotopes, Geology, 5, 400-404, 1977.

Tripati, A. K., Eagle, R. A., Thiagarajan, N., Gagnon, A. C., Bauch, H., Halloran, P. R., and Eiler, J. M.: ${ }^{13} \mathrm{C}-{ }^{18} \mathrm{O}$ isotope signatures and "clumped isotope" thermometry in foraminifera and coccoliths, Geochim. Cosmochim. Ac., 74, 5697-5717, 2010.

Watkins, J. M., Nielsen, L. C., Ryerson, F. J., and DePaolo, D. J.: The influence of kinetics on the oxygen isotope composition of calcium carbonate, Earth Planet. Sc. Lett., 375, 349-360, 2013.

Watkins, J. M., Hunt, J. D., Ryerson, F. J. and DePaolo, D. J.: The influence of temperature, $\mathrm{pH}$, and growth rate on the $\delta^{18} \mathrm{O}$ composition of inorganically precipitated calcite, Earth Planet. Sc. Lett., 404, 332-343, 2014.

Young, J., Geisen, M., Cros, L., Kleijne, A., Sprengel, C., Probert, I. and Ostergaard, J. B.: A guide to extant coccolithophore taxonomy, J. Nannoplankt. Res. Spec. Issue, 1, 1-125, 2003.

Young, J. R., Poulton, A. J., and Tyrrell, T.: Morphology of Emiliania huxleyi coccoliths on the northwestern European shelf - is there an influence of carbonate chemistry?, Biogeosciences, 11, 4771-4782, doi:10.5194/bg-11-4771-2014, 2014. 
Zeebe, R. E. and Wolf-Gladrow, D.: $\mathrm{CO}_{2}$ in Seawater: Equilibrium, Kinetics, Isotopes, Elsevier, Amsterdam, the Netherlands, 2001.

Ziveri, P., Stoll, H., Probert, I., Klaas, C., Geisen, M., Ganssen, G., and Young, J.: Stable isotope "vital effects" in coccolith calcite, Earth Planet. Sc. Lett., 210, 137-149, 2003.
Ziveri, P., Thoms, S., Probert, I., Geisen, M., and Langer, G.: A universal carbonate ion effect on stable oxygen isotope ratios in unicellular planktonic calcifying organisms, Biogeosciences, 9, 1025-1032, doi:10.5194/bg-9-1025-2012, 2012. 